
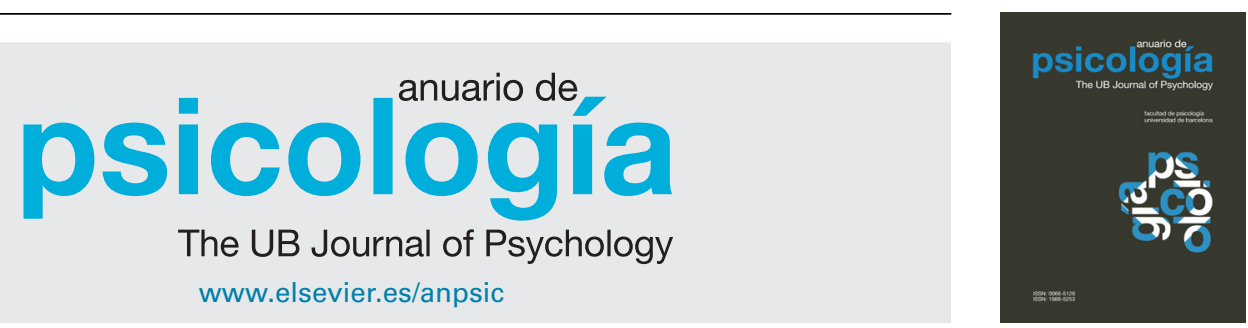

THEMATIC REVIEWS

\title{
Twenty-five years of research on work and organizational psychology: A bibliometric perspective
}

\author{
Marina Romeo $^{a, *}$, Montserrat Yepes-Baldó ${ }^{a}$, Sefa Boria-Reverter ${ }^{b}$, José M. Merigó ${ }^{c}$ \\ a Research Group in Social, Environmental and Organizational Psychology (2014SGR992), Faculty of Psychology, University \\ of Barcelona, Barcelona, Spain \\ ${ }^{\mathrm{b}}$ Faculty of Economics and Business, University of Barcelona, Barcelona, Spain \\ ${ }^{c}$ Faculty of Economics and Business, University of Chile, Santiago de Chile, Chile
}

Received 11 November 2016; accepted 27 April 2017

Available online 9 June 2017

\section{KEYWORDS \\ Work and organizational psychology; $h$-index; Citation; Bibliometrics}

\section{PALABRAS CLAVE}

Psicología del trabajo y de las organizaciones; Índice h; Citación; Bibliometría

\begin{abstract}
The research aims to analyze the scientific productivity in the field of work/organizational psychology (WOP) in the last 25 years. We focus our analysis on the most influential journals and articles, generally and for 5-year periods, as well as structures of co-citation among the highest quality journals based on their $h$-index. We found that a high percentage of papers published each year receive between 5 and 10 cites. Secondly, we observe an exponential increase in the number of papers published, citations, and $h$-index. Additionally, the number of self-citations significantly increases in the last 5 years. In this sense, we consider that the most recent papers need more time to increase their level of citation and, subsequently, to correct the bias on self-citation. This research shows the status of research in the field of work/organizational psychology, analyzing the scientific journals and papers published in the Web of Science.

(c) 2017 Universitat de Barcelona. Published by Elsevier España, S.L.U. All rights reserved.
\end{abstract}

\begin{abstract}
Veinticinco años de investigación en psicología del trabajo y de las organizaciones: una perspectiva bibliométrica
\end{abstract}

Resumen La presente investigación tiene como objetivo analizar la producción científica en el ámbito de la psicología del trabajo y las organizaciones en los últimos 25 años. Centramos nuestro análisis en las revistas y artículos con el nivel más alto de índice $h$, en general y por períodos de 5 años, así como en las estructuras de cocitación entre ellas. Los resultados muestran que un alto porcentaje de artículos reciben entre 5 y 10 citas. En segundo lugar, se observa un aumento exponencial en el número de trabajos publicados, las citas, así como el

\footnotetext{
* Corresponding author.

E-mail address: mromeo@ub.edu (M. Romeo).
} 
índice $h$. Además, el número de autocitas aumenta significativamente en los trabajos publicados en los últimos 5 años. En este sentido, consideramos que los documentos más recientes necesitan más tiempo para aumentar su nivel de citación y, posteriormente, para corregir el sesgo de autocita. La presente investigación muestra el estado de la investigación en el ámbito de la psicología del trabajo y de las organizaciones a partir del análisis de las revistas y artículos científicos publicados en la Web of Science.

() 2017 Universitat de Barcelona. Publicado por Elsevier España, S.L.U. Todos los derechos reservados.

\section{Introduction}

Different disciplines, as psychology and management, have contributed to the development of work and organizational psychology (WOP) (König, Fell, Kellnhofer, \& Schui, 2015). In this regard, Aguinis, Bradley, and Brodersen (2014) consider that the relationship between industrial and organizational psychology and management is increasing, and there is evidence of an increased presence of $1-0$ psychologists in business schools.

The WOP interdisciplinary' has shown is present in diverse scientific journals. This is a great strength, as it contributes to sharing knowledge in various fields, but also implies a difficulty because researchers have widened the focus of analysis on conceptually and methodologically terms.

In this sense, a bibliometric study focused on the contributions of work and organizational psychology (WOP) is important in order to show the status of research in this field.

\section{Bibliometric studies related to work and organizational psychology (WOP)}

There have been various bibliometric studies in relation to the different areas of intervention of psychology: Psychology of Personality (Allik, 2013a; Aluja et al., 2011; Haslam et al., 2008), Social Psychology (Allik, 2013b; Cikara, Rudman, \& Fiske, 2012; Haslam \& Kashima, 2010), Educational and Developmental Psychology (Albayrak, Föcker, Wibker, \& Hebebrand, 2012; Campanario, González, \& Rodríguez, 2006; Vinluan, 2012), Clinical and Health Psychology (Ariza \& Reina Granados, 2012; Haslam \& Lusher, 2011; Lillo \& Martini, 2013; Quevedo-Blasco, Zych, \& BuelaCasal, 2014), or Neuropsychology (Lepach, Lehmkuhl, \& Petermann, 2010).

However, few bibliometric studies focus on the field of WOP have been published in journals included on WoS (König et al., 2015; Viseu, de Jesus, Quevedo-Blasco, Rus, \& Canavarro, 2015).

The recent decease of Dr. Robert A. Roe, foundingpresident (1991-1995) of the European Association of Work and Organizational Psychology (EAWOP), has inspired this research, which main objective is to analyze the research productivity in the field of WOP, focusing on the most influential journals and articles in the last 25 years (1991-2015).

\section{Method}

The utility of bibliometric studies lies in their ability to evidence the general state of research in a particular field of study (Bonilla, Merigó, \& Torres-Abad, 2015). There are different indicators to indicate the degree of influence of a magazine or paper in a particular field of study. Commonly used are the inclusion of the journal in prestigious indexing databases such as the Web of Science (Merigó, Gil-Lafuente, \& Yager, 2015), their annual impact factor (Garfield, 1972; Glanzer \& Moed, 2002) and 5-year impact factor (Amin \& Mabe, 2003; Campanario, 2011), the number of papers published in a period of time (Goldberg, Anthony, \& Evans, 2015), the number of citations received (Podsakoff, MacKenzie, Podsakoff, \& Bachrach, 2008), the $h$-index (Hirsch, 2005; Hirsch \& Buela-Casal, 2014), the ratio cites/paper (Merigó, Mas-Tur, Roig-Tierno, \& Ribeiro-Soriano, 2015), or the ratio papers/year (Goldberg et al., 2015).

In the present study, we use a combination of indicators, in order to provide the maximum information and a global perspective. Specifically, we analyze the citation structure in the past 25 years. This analysis allows the establishing of the annual diffusion pattern based on the number of citations received by papers published in a given year, as well as the evolution of that pattern.

Secondly, we analyze the ranking of the most influential journals in the field of WOP from their $h$-index, the number of papers published, citations received, the average number of citations per article, the impact factor (IF) and 5-year impact factor. Additionally, we indicate how many of the 50 most influential articles, in relation to the number of citations they receive, have been published in these journals.

Thirdly, we analyze the temporal evolution of the most important journals in the area, in periods of 5 years, in the number of published papers, the $h$-index and the number of citations (total and average per year). In addition, in order to analyze the influence of self-citation in the results, we show the longitudinal trend of the relationship between citations and self-citations in a 5 -year period.

Fourthly, we analyze the knowledge flows established between the top- 5 journals by $h$-index in order to establish relations of co-citation among the most influential 
journals in WOP. Some authors suggest that this structure of co-citations affects the prestige of a journal on account of being cited by others with high rates of reputation (Simsek, Heavey, \& Jansen, 2013).
Finally, we analyze the 50 papers that have received more citations in the last 25 years, the journals that have published them, the authors and the relationships between them.

Table 1 General citation structure.

\begin{tabular}{|c|c|c|c|c|c|c|c|}
\hline & $\geq 100$ & $\geq 50$ & $\geq 10$ & $\geq 5$ & $\geq 1$ & No. of cited papers & Total \\
\hline \multirow{2}{*}{1991} & 67 & 62 & 189 & 52 & 78 & 59 & 507 \\
\hline & $13.21 \%$ & $12.23 \%$ & $37.28 \%$ & $10.26 \%$ & $15.38 \%$ & $11.64 \%$ & $100 \%$ \\
\hline \multirow{2}{*}{1992} & 70 & 76 & 222 & 59 & 82 & 30 & 539 \\
\hline & $12.99 \%$ & $14.10 \%$ & $41.19 \%$ & $10.95 \%$ & $15.21 \%$ & $5.57 \%$ & $100 \%$ \\
\hline \multirow{2}{*}{1993} & 77 & 86 & 231 & 64 & 61 & 32 & 551 \\
\hline & $13.97 \%$ & $15.61 \%$ & $41.92 \%$ & $11.62 \%$ & $11.07 \%$ & $5.81 \%$ & $100 \%$ \\
\hline \multirow{2}{*}{1994} & 79 & 96 & 270 & 73 & 67 & 50 & 635 \\
\hline & $12.44 \%$ & $15.12 \%$ & $42.52 \%$ & $11.50 \%$ & $10.55 \%$ & $7.87 \%$ & $100 \%$ \\
\hline \multirow{2}{*}{1995} & 75 & 106 & 290 & 78 & 99 & 42 & 690 \\
\hline & $10.87 \%$ & $15.36 \%$ & $42.03 \%$ & $11.30 \%$ & $14.35 \%$ & $6.09 \%$ & $100 \%$ \\
\hline \multirow[b]{2}{*}{1996} & 84 & 86 & 290 & 100 & 114 & 34 & 708 \\
\hline & $11.86 \%$ & $12.15 \%$ & $40.96 \%$ & $14.12 \%$ & $16.10 \%$ & $4.80 \%$ & $100 \%$ \\
\hline \multirow{2}{*}{1997} & 98 & 101 & 294 & 98 & 137 & 116 & 844 \\
\hline & $11.61 \%$ & $11.97 \%$ & $34.83 \%$ & $11.61 \%$ & $16.23 \%$ & $13.74 \%$ & $100 \%$ \\
\hline \multirow{2}{*}{1998} & 91 & 101 & 296 & 86 & 141 & 136 & 851 \\
\hline & $10.69 \%$ & $11.87 \%$ & $34.78 \%$ & $10.11 \%$ & $16.57 \%$ & $15.98 \%$ & $100 \%$ \\
\hline \multirow{2}{*}{1999} & 107 & 121 & 344 & 107 & 149 & 126 & 954 \\
\hline & $11.22 \%$ & $12.68 \%$ & $36.06 \%$ & $11.22 \%$ & $15.62 \%$ & $13.21 \%$ & $100 \%$ \\
\hline \multirow{2}{*}{2000} & 111 & 134 & 332 & 92 & 117 & 134 & 920 \\
\hline & $12.07 \%$ & $14.57 \%$ & $36.09 \%$ & $10.00 \%$ & $12.72 \%$ & $14.57 \%$ & $100 \%$ \\
\hline \multirow[b]{2}{*}{2001} & 123 & 145 & 362 & 95 & 111 & 128 & 964 \\
\hline & $12.76 \%$ & $15.04 \%$ & $37.55 \%$ & $9.85 \%$ & $11.51 \%$ & $13.28 \%$ & $100 \%$ \\
\hline \multirow{2}{*}{2002} & 130 & 141 & 380 & 108 & 99 & 24 & 882 \\
\hline & $14.74 \%$ & $15.99 \%$ & $43.08 \%$ & $12.24 \%$ & $11.22 \%$ & $2.72 \%$ & $100 \%$ \\
\hline \multirow{2}{*}{2003} & 111 & 164 & 381 & 89 & 96 & 21 & 862 \\
\hline & $12.88 \%$ & $19.03 \%$ & $44.20 \%$ & $10.32 \%$ & $11.14 \%$ & $2.44 \%$ & $100 \%$ \\
\hline \multirow{2}{*}{2004} & 103 & 136 & 450 & 85 & 74 & 41 & 889 \\
\hline & $11.59 \%$ & $15.30 \%$ & $50.62 \%$ & $9.56 \%$ & $8.32 \%$ & $4.61 \%$ & $100 \%$ \\
\hline \multirow{2}{*}{2005} & 87 & 167 & 501 & 140 & 104 & 19 & 1018 \\
\hline & $8.55 \%$ & $16.40 \%$ & $49.21 \%$ & $13.75 \%$ & $10.22 \%$ & $1.87 \%$ & $100 \%$ \\
\hline \multirow{2}{*}{2006} & 103 & 142 & 482 & 153 & 112 & 39 & 1031 \\
\hline & $9.99 \%$ & $13.77 \%$ & $46.75 \%$ & $14.84 \%$ & $10.86 \%$ & $3.78 \%$ & $100 \%$ \\
\hline \multirow[b]{2}{*}{2007} & 87 & 131 & 567 & 189 & 141 & 38 & 1153 \\
\hline & $7.55 \%$ & $11.36 \%$ & $49.18 \%$ & $16.39 \%$ & $12.23 \%$ & $3.30 \%$ & $100 \%$ \\
\hline \multirow{2}{*}{2008} & 44 & 128 & 671 & 251 & 207 & 50 & 1351 \\
\hline & $3.26 \%$ & $9.47 \%$ & $49.67 \%$ & $18.58 \%$ & $15.32 \%$ & $3.70 \%$ & $100 \%$ \\
\hline \multirow{2}{*}{2009} & 32 & 117 & 794 & 319 & 279 & 69 & 1610 \\
\hline & $1.99 \%$ & $7.27 \%$ & $49.32 \%$ & $19.81 \%$ & $17.33 \%$ & $4.29 \%$ & $100 \%$ \\
\hline & 29 & 71 & 739 & 358 & 389 & 98 & 1684 \\
\hline 2010 & $1.72 \%$ & $4.22 \%$ & $43.88 \%$ & $21.26 \%$ & $23.10 \%$ & $5.82 \%$ & $100 \%$ \\
\hline & 13 & 47 & 626 & 448 & 565 & 146 & 1845 \\
\hline 2011 & $0.70 \%$ & $2.55 \%$ & $33.93 \%$ & $24.28 \%$ & $30.62 \%$ & $7.91 \%$ & $100 \%$ \\
\hline & 2 & 13 & 445 & 443 & 769 & 246 & 1918 \\
\hline 2012 & $0.10 \%$ & $0.68 \%$ & $23.20 \%$ & $23.10 \%$ & $40.09 \%$ & $12.83 \%$ & $100 \%$ \\
\hline & 0 & 5 & 201 & 394 & 966 & 389 & 1955 \\
\hline 2013 & $0.00 \%$ & $0.26 \%$ & $10.28 \%$ & $20.15 \%$ & $49.41 \%$ & $19.90 \%$ & $100 \%$ \\
\hline & 0 & 1 & 56 & 175 & 977 & 794 & 2003 \\
\hline 2014 & $0.00 \%$ & $0.05 \%$ & $2.80 \%$ & $8.74 \%$ & $48.78 \%$ & $39.64 \%$ & $100 \%$ \\
\hline & 0 & 0 & 0 & 18 & 445 & 1639 & 2102 \\
\hline 2015 & $0.00 \%$ & $0.00 \%$ & $0.00 \%$ & $0.86 \%$ & $21.17 \%$ & $77.97 \%$ & $100 \%$ \\
\hline Total & 1723 & 2377 & 9413 & 4074 & 6379 & 4500 & 28,466 \\
\hline$\%$ & $6.1 \%$ & $8.4 \%$ & $33.1 \%$ & $14.3 \%$ & $22.4 \%$ & $15.8 \%$ & $100.0 \%$ \\
\hline
\end{tabular}

Highest percentatge by row is indicated by italics. 
To reach our objectives we used the database Web of Science as a source of information, since it is currently considered the most important and influential database in international scientific research (Merigó, Mas-Tur, et al., 2015; Viseu et al., 2015). The search strategy was developed in January 2016. Given the interdisciplinary nature of the field, indicated in the introduction, we decided not to focus exclusively on the journals indexed in the management or psychology categories of WoS but search by topic, regardless of the category in which the sources are placed.

\section{Results}

In January 2016 (timespan: 1991-2015), there were 37,505 papers in WoS Core Collection. If only articles and reviews are considered, the number is reduced to 28,500 $(26,849$ articles and 1651 reviews). The global $h$-index according to the selected papers was 285 (that is, 285 papers have received at least 285 citations).

\section{Citation structure}

An important issue when analyzing the publication and citation structure is to consider the number of papers that have surpassed a citation threshold. This indicates the level of citation that most of the papers receive and permit us to identify the number of citations that the top papers usually receive.

Results show that a high percentage of papers published each year receive between 5 and 10 cites (Table 1 ). This trend is maintained until 2011-2012, when the number of citations per paper decreases (reaching between 1 and 4 cites). $6.1 \%$ of articles published in the period 1991-2015 receive 100 or more citations.

Additionally, we considered it appropriate to differentiate between self-citations and citations received (Fig. 1). In this sense, we observed that in the last 5 years a significant increase in self-citations, which reaches $25 \%$ of all citations received, occurs.

\section{Journals ranking}

This section presents the ranking of the most influential WOP journals, according to the data available in WoS (Table 2). In this regard, the most influential journal in this field is the Journal of Applied Psychology (JAP). Although the JAP is in the first position of the ranking in terms of number of papers, $h$-index and citations (self-cites excluded), is the second in citations per paper $(C / P)$, where the Journal of Consumer Behaviour (JCB) is the first. JAP is also in second position on impact factor (IF-2014) and on 5-year impact factor, being surpassed by the Journal of Management (JOM).

Another indicator of the relevance of the JAP and the JOM in the area under study is that 12 and 7 of the 50 most cited articles of the last 25 years have been published in JAP and JOM respectively, representing $24 \%$ and $14 \%$ of the total (see Table 6 for more information).

\section{Temporary evolution of the journals}

We consider it interesting to analyze the differences in the top- 5 journals segmenting by 5 -year periods (Table 3 ).

The JAP appears again as the journal with the highest $h$ index in all periods, followed by JOM, which varies between the second and third place alternately with the Organizational Behavior and Human Decision Processes (OBHDP) journal in the first two 5-year periods, with JOB in the period 2001-2005, and Leadership Quarterly (LQ) in the last two periods.

Going into detail on other quality indicators of the journals above mentioned, as we had already seen in the previous section, there exist an alternation between the JAP and the JOM based on the average of citations per published paper. In this regard, in the first 5 years analyzed, the JOM has a higher average of citations per paper, although both have a similar average in the next period and the trend analyzed in 2001-2005 (Table 4).

\section{Knowledge flow}

In this section, we present the citations structure from among the 5 most influential journals based on their $h$-index

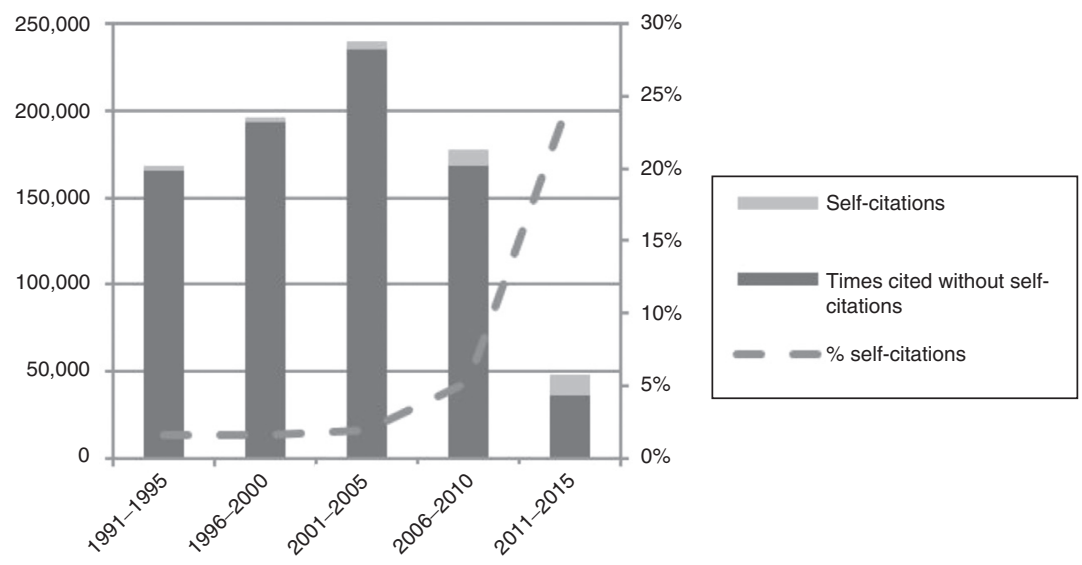

Figure 1 Citations and self-citation by 5-year periods. 
Table 2 Most influencial WOP journals.

\begin{tabular}{|c|c|c|c|c|c|c|c|c|}
\hline $\mathrm{R}$ & Source titles & Papers & $h$-index & $\begin{array}{l}\text { Citations } \\
\text { (self-cites } \\
\text { excluded) }\end{array}$ & $\mathrm{C} / \mathrm{P}$ & IF (2014) & IF5 & T50 \\
\hline 1 & $\begin{array}{l}\text { Journal of Applied Psychology } \\
\text { (JAP) }\end{array}$ & 2311 & 194 & 171,760 & 80.09 & 4.799 & 7.753 & 12 \\
\hline 2 & Journal of Management (JOM) & 1123 & 136 & 78,802 & 72.66 & 6.071 & 9.238 & 7 \\
\hline 3 & $\begin{array}{l}\text { Journal of Organizational } \\
\text { Behavior (JOB) }\end{array}$ & 1291 & 112 & 53,670 & 43.29 & 3.038 & 5.017 & 1 \\
\hline 4 & $\begin{array}{l}\text { Organizational Behavior and } \\
\text { Human Decision Processes } \\
\text { (OBHDP) }\end{array}$ & 1435 & 110 & 66,577 & 48.66 & 2.201 & 3.938 & 4 \\
\hline 5 & Personnel Psychology (PP) & 680 & 105 & 41,846 & 64.39 & 4.49 & 6.227 & 3 \\
\hline 6 & Leadership Quarterly (LQ) & 910 & 85 & 26,440 & 36.64 & 3.138 & 4.326 & 1 \\
\hline 7 & $\begin{array}{l}\text { Journal of Occupational and } \\
\text { Organizational Psychology } \\
\text { (JOOP) }\end{array}$ & 792 & 70 & 22,227 & 29.19 & 1.667 & 3.461 & - \\
\hline 8 & $\begin{array}{l}\text { Organizational Research } \\
\text { Methods (ORM) }\end{array}$ & 435 & 62 & 18,656 & 45.1 & 4.148 & 5.465 & 2 \\
\hline 9 & $\begin{array}{l}\text { Research in Organizational } \\
\text { Behavior (ROB) }\end{array}$ & 178 & 60 & 12,626 & 72.12 & 1.562 & 3.4 & 3 \\
\hline 10 & $\begin{array}{l}\text { Journal of Consumer Research } \\
\text { (JoCR) }\end{array}$ & 134 & 59 & 12,948 & 97.91 & 3.125 & 5.003 & 2 \\
\hline 11 & $\begin{array}{l}\text { Journal of Consumer } \\
\text { Psychology (JCP) }\end{array}$ & 720 & 54 & 11,860 & 18.57 & 2.243 & 2.561 & - \\
\hline 12 & $\begin{array}{l}\text { Human Resource Management } \\
\text { (HRM) }\end{array}$ & 812 & 53 & 12,778 & 17.06 & 1.293 & 2.705 & - \\
\hline 13 & Organizational Dynamics (OD) & 671 & 52 & 10,645 & 16.15 & 0.789 & 0.841 & - \\
\hline 14 & $\begin{array}{l}\text { Group Organization } \\
\text { Management (GOM) }\end{array}$ & 553 & 52 & 10,545 & 20.53 & 1.40 & 2.869 & - \\
\hline 15 & Small Group Research (SGR) & 704 & 51 & 10,937 & 17.27 & 0.794 & 1.612 & - \\
\hline 16 & $\begin{array}{l}\text { Journal of Business and } \\
\text { Psychology (JBP) }\end{array}$ & 784 & 39 & 8266 & 11.06 & 2.075 & 3.015 & - \\
\hline 17 & $\begin{array}{l}\text { International Journal of } \\
\text { Selection And Assessment } \\
\text { (IJSA) }\end{array}$ & 691 & 38 & 7373 & 12.55 & 0.814 & 1.199 & - \\
\hline 18 & $\begin{array}{l}\text { Journal of Business Research } \\
\text { (JBR) }\end{array}$ & 243 & 37 & 4695 & 19.67 & 1.48 & 2.324 & - \\
\hline 19 & Personnel Review (PR) & 876 & 34 & 6985 & 8.63 & 0.921 & 1.438 & - \\
\hline 20 & $\begin{array}{l}\text { European Journal of Work and } \\
\text { Organizational Psychology } \\
\text { (EJWOP) }\end{array}$ & 380 & 31 & 3876 & 10.86 & 2.09 & 2.615 & - \\
\hline 21 & Psychology Marketing (PM) & 158 & 30 & 2599 & 16.95 & 1.080 & 1.547 & - \\
\hline 22 & Journal of Business Ethics (JBE) & 169 & 28 & 2411 & 15.2 & 1.326 & 1.915 & - \\
\hline 23 & $\begin{array}{l}\text { Journal of Managerial } \\
\text { Psychology (JMP) }\end{array}$ & 366 & 24 & 2495 & 7.44 & 1.20 & 1.919 & - \\
\hline 24 & $\begin{array}{l}\text { Journal of Organizational } \\
\text { Behavior Management (JOBM) }\end{array}$ & 300 & 21 & 1139 & 7.29 & 0.486 & 0.967 & - \\
\hline 25 & $\begin{array}{l}\text { European Journal of Marketing } \\
\text { (EJM) }\end{array}$ & 175 & 20 & 1453 & 8.6 & 1.006 & 1.659 & - \\
\hline
\end{tabular}

(Table 5). Results show that, even though the JAP is the most cited journal $(62,845$ cites), only $4.27 \%$ of its citations comes from the other top- 5 journals. On the other hand, Personnel Psychology (PP) has the lowest number of cites $(22,162)$, but $10.46 \%$ of them come from top- 5 journals.
The rank of self-citations is between $1.6 \%$ (JAP) and $4.38 \%$ (JOB).

Next, let us look into the general co-citation structure of the most representative journals in this field (Fig. 2). For doing so, we use the VOS viewer software (Van Eck \& 
Table 3 Ranking of the 5 most influential WOP journals by 5 -year periods.

\begin{tabular}{|c|c|c|c|c|c|c|}
\hline Source titles & 1991-1995 & $1996-2000$ & $2001-2005$ & $2006-2010$ & $2011-2015$ & Mean rank \\
\hline $\begin{array}{l}\text { Journal of Applied } \\
\text { Psychology (JAP) }\end{array}$ & 1 & 1 & 1 & 1 & 1 & 1 \\
\hline $\begin{array}{l}\text { Journal of Management } \\
\text { (JOM) }\end{array}$ & 3 & 2 & 3 & 2 & 2 & 2.4 \\
\hline $\begin{array}{l}\text { Organizational Behavior } \\
\text { and Human Decision } \\
\text { Processes (OBHDP) }\end{array}$ & 2 & 3 & 4 & 5 & - & 3.5 \\
\hline $\begin{array}{l}\text { Leadership Quarterly } \\
\text { (LQ) }\end{array}$ & - & - & 5 & 3 & 3 & 3.67 \\
\hline $\begin{array}{l}\text { Journal of Organizational } \\
\text { Behavior (JOB) }\end{array}$ & 5 & 4 & 2 & 4 & 4 & 3.8 \\
\hline $\begin{array}{l}\text { Personnel Psychology } \\
\text { (PP) }\end{array}$ & 4 & 5 & - & - & 5 & 4.67 \\
\hline
\end{tabular}

Table 4 Quality indicators of top-5 journals (5-year periods).

\begin{tabular}{|c|c|c|c|c|c|c|c|}
\hline Period & Indicators & JAP & JOM & OBHDP & LQ & JOB & PP \\
\hline \multirow{5}{*}{ 1991-1995 } & Rank & 1 & 3 & 2 & - & 5 & 4 \\
\hline & Papers & 410 & 205 & 361 & - & 190 & 145 \\
\hline & $h$ & 107 & 66 & 72 & - & 55 & 56 \\
\hline & Citations (self-cites excluded) & 38,810 & 24,696 & 28,657 & - & 10,937 & 14,450 \\
\hline & $\mathrm{C} / \mathrm{P}$ & 95.37 & 120.98 & 80.04 & - & 57.77 & 100.37 \\
\hline \multirow{5}{*}{$1996-2000$} & Rank & 1 & 2 & 3 & - & 4 & 5 \\
\hline & Papers & 398 & 184 & 317 & - & 258 & 148 \\
\hline & $h$ & 114 & 78 & 77 & - & 70 & 61 \\
\hline & Citations (self-cites excluded) & 42,194 & 20,092 & 19,390 & - & 14,679 & 11,010 \\
\hline & $\mathrm{C} / \mathrm{P}$ & 106.88 & 109.45 & 61.87 & - & 57.11 & 74.86 \\
\hline \multirow{5}{*}{ 2001-2005 } & Rank & 1 & 3 & 4 & 5 & 2 & - \\
\hline & Papers & 504 & 199 & 225 & 160 & 250 & - \\
\hline & $h$ & 126 & 75 & 62 & 66 & 78 & - \\
\hline & Citations (self-cites excluded) & 63,522 & 18,055 & 11,305 & 11,578 & 18,425 & - \\
\hline & $\mathrm{C} / \mathrm{P}$ & 127.04 & 91.12 & 50.59 & 73.94 & 74.12 & - \\
\hline \multirow{5}{*}{ 2006-2010 } & Rank & 1 & 2 & 5 & 3 & 4 & - \\
\hline & Papers & 552 & 226 & 231 & 253 & 262 & - \\
\hline & $h$ & 98 & 67 & 48 & 53 & 50 & - \\
\hline & Citations (self-cites excluded) & 33,683 & 14,007 & 7808 & 8877 & 9008 & - \\
\hline & $\mathrm{C} / \mathrm{P}$ & 62.27 & 62.56 & 34.19 & 37.11 & 34.82 & - \\
\hline \multirow{5}{*}{$2011-2015$} & Rank & 1 & 2 & - & 3 & 4 & 5 \\
\hline & Papers & 447 & 309 & - & 357 & 331 & 124 \\
\hline & $h$ & 34 & 33 & - & 22 & 21 & 22 \\
\hline & Citations (self-cites excluded) & 4584 & 4204 & - & 1924 & 2336 & 1587 \\
\hline & $\mathrm{C} / \mathrm{P}$ & 11.32 & 14.21 & - & 7.19 & 7.63 & 13.27 \\
\hline Mean rank & & 1.00 & 2.40 & 3.50 & 3.67 & 3.80 & 4.67 \\
\hline
\end{tabular}

Waltman, 2010). Recall that co-citation occurs when two documents receive a citation by the same third document (Small, 1973).

The Journal of Applied Psychology has the deepest cocitation structure. Most of the leading journals are close to the field (Journal of Personality and Social Psychology) although some management journals also have a significant position including the Academy of Management Journal and the Academy of Management Review. Some other journals in marketing and economics also appear in the map although their influence is lower.

\section{The most influential papers}

In this section, we considered of interest to researchers in the field of WOP to analyze the 50 most cited articles in the period under study (Table 6). The most influential paper in 
Table 5 Citations structure among the 5 most influential journals.

\begin{tabular}{|c|c|c|c|c|c|c|c|}
\hline & & \multicolumn{6}{|c|}{ Cited journals } \\
\hline & & JAP & JOM & OBHDP & JOB & PP & Total row \\
\hline \multirow{7}{*}{$\begin{array}{l}\text { Citing } \\
\text { journals }\end{array}$} & JAP & $43(1.6 \%)$ & 981 (61.5\%) & 906 (46.92\%) & 930 (52.84\%) & 1170 (50.5\%) & 3987 \\
\hline & JOM & $642(23.92 \%)$ & $66(4.14 \%)$ & 368 (19.06\%) & 404 (22.96\%) & 452 (19.42\%) & 1866 \\
\hline & OBHDP & $525(19.56 \%)$ & $248(15.55 \%)$ & $43(2.23 \%)$ & $180(10.24 \%)$ & $190(8.2 \%)$ & 1143 \\
\hline & $\mathrm{JOB}$ & $922(34.35 \%)$ & 63 (3.95\%) & $428(22.17 \%)$ & 77 (4.38\%) & 505 (21.8\%) & 1918 \\
\hline & $\mathrm{PP}$ & $595(22.17 \%)$ & $303(19.0 \%)$ & $229(11.86 \%)$ & $246(13.98 \%)$ & $42(1.81 \%)$ & 1373 \\
\hline & Total column & $2684(4.27 \%)$ & 1595 (3.55\%) & 1931 (4.56\%) & $1760(6.25 \%)$ & 2317 (10.46\%) & 10,287 \\
\hline & Total cites & 62,845 & 44,893 & 42,391 & 28,179 & 22,162 & \\
\hline
\end{tabular}

Self-citations are indicated by italics.

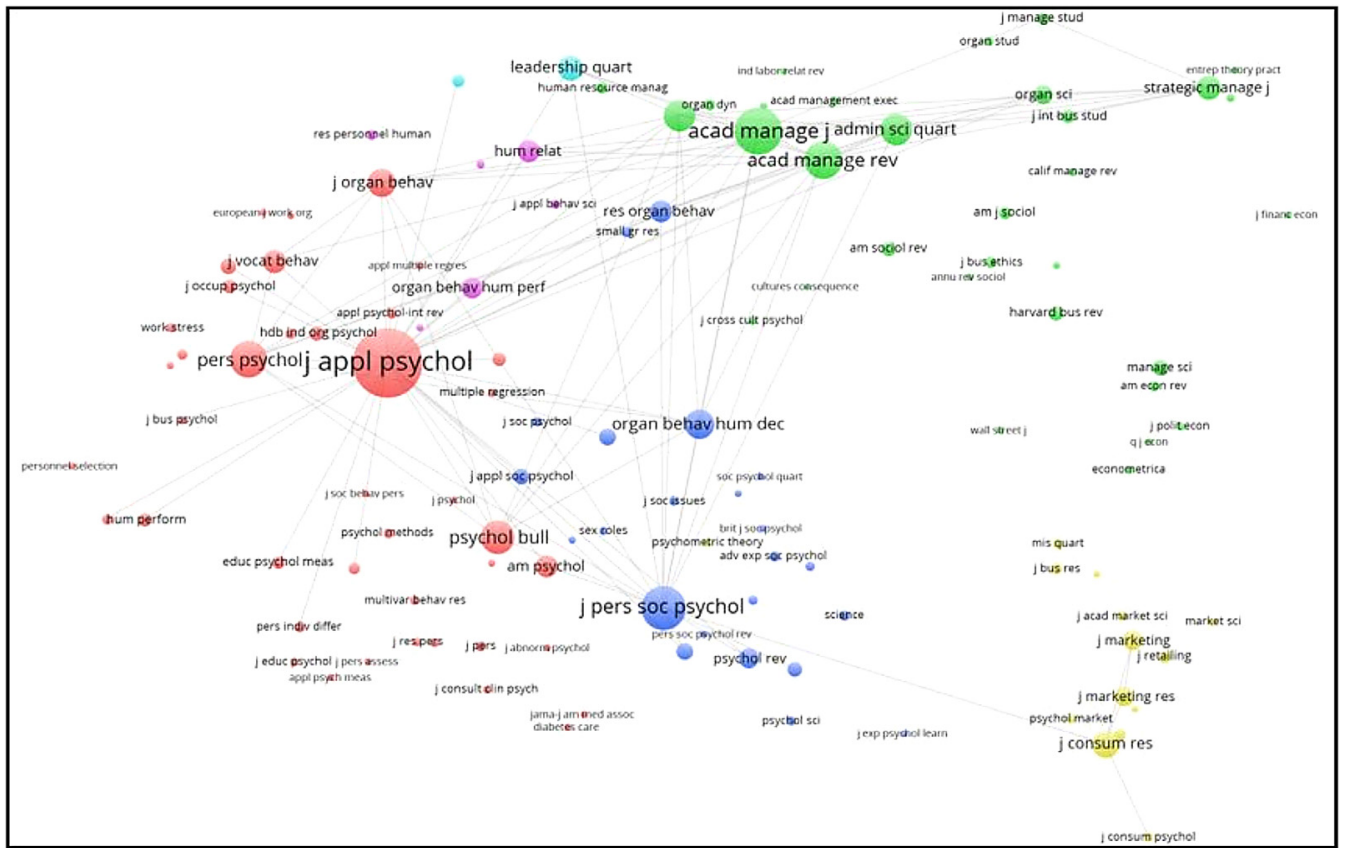

Figure 2 Co-citation structure of journals on work and organizational psychology.

this area was published by Icek Ajzen in 1991. In this paper the author developed the well-known theory of planned behavior, defined by him as, "a useful conceptual framework for dealing with the complexities of human social behavior"' (Ajzen, 1991, p. 206).

Ajzen's paper is the most cited in absolute terms, but Podsakoff's and collaborators paper (2003) receives more citations on average (correcting the number of citations by taking into account the year of the article). This paper reviews one of the most common methodological problems of the discipline and, in general, in the social sciences, the common method variance. In this sense, this analysis is entirely relevant to researchers when designing their own research, as it provides recommendations for controlling method biases in research settings.

Although we observed that the articles published in the period 1991-1995 were the most cited, 2001 was the year when most of the top-50 papers were published $(18 \%$ of total). Consistently with the previous results, in 1991seven top-50 papers were published (14\%)
Additionally, we analyzed the 19 journals in which the top-50 papers have been published. Five of these exceed the median of items included in the top-50 $(\mathrm{Md}=2)$. They are the Journal of Applied Psychology (with 24\% of papers on the list of the most influential), the Journal of Management (14\%), Organizational Behavior and Human Decision Processes (8\%), the MIS Quarterly, and Personnel Psychology $(6 \%)$. Finally, 15 of the most cited papers have been published in journals not included in the list of top-25 most influential (Fig. 3).

The most influential authors by number of papers published are Wilmar B. Schaufeli, with 3 papers in the Journal of Applied Psychology (2001), the Annual Review of Psychology (2001) and the Journal of Organizational Behavior (2004). Secondly, publishing two papers, we found Blake E. Ashforth (JOB, 1992; JAP, 1996), Arnold B. Bakker (JAP, 2001; JOB, 2004, with Schaufeli as a co-author in both), Jason A. Colquitt (2 papers on the JAP in 2001), Russell Cropanzano (Research in Organizational Behavior, 1996; JOM, 2005), Scott B. MacKenzie (JOM, 2000 and JAP, 2003, 
Table 6 The 50 most cited papers.

\begin{tabular}{|c|c|c|c|c|c|c|}
\hline $\mathrm{R}$ & Authors & Title & Year & Journal & Cites & $\mathrm{C} / \mathrm{Y}$ \\
\hline 1 & Ajzen & The theory of planned behavior & 1991 & $\begin{array}{l}\text { Organizational } \\
\text { Behavior and Human } \\
\text { Decision Processes }\end{array}$ & 11,466 & 477.8 \\
\hline 2 & Barney & $\begin{array}{l}\text { Firm resources and sustained } \\
\text { competitive advantage }\end{array}$ & 1991 & $\begin{array}{l}\text { Journal of } \\
\text { Management }\end{array}$ & 9164 & 381.8 \\
\hline 3 & $\begin{array}{l}\text { Podsakoff, } \\
\text { Mackenzie, Lee, } \\
\text { and Podsakoff }\end{array}$ & $\begin{array}{l}\text { Common method biases in } \\
\text { behavioral research: A critical } \\
\text { review of the literature } \\
\text { and recommended remedies }\end{array}$ & 2003 & $\begin{array}{l}\text { Journal of Applied } \\
\text { Psychology }\end{array}$ & 8777 & 731.4 \\
\hline 4 & Barrick and Mount & $\begin{array}{l}\text { The big } 5 \text { personality dimensions } \\
\text { and job-performance - } \\
\text { A metaanalysis }\end{array}$ & 1991 & Personnel Psychology & 2207 & 92.0 \\
\hline 5 & $\begin{array}{l}\text { Maslach, } \\
\text { Schaufeli, } \\
\text { and Leiter }\end{array}$ & Job burnout & 2001 & $\begin{array}{l}\text { Annual Review of } \\
\text { Psychology }\end{array}$ & 2066 & 147.6 \\
\hline 6 & $\begin{array}{l}\text { Vandenberg } \\
\text { and Lance }\end{array}$ & $\begin{array}{l}\text { A review and synthesis of the } \\
\text { measurement invariance literature: } \\
\text { Suggestions, practices, and } \\
\text { recommendations for organizational } \\
\text { research }\end{array}$ & 2000 & $\begin{array}{l}\text { Organizational } \\
\text { Research Methods }\end{array}$ & 1702 & 113.5 \\
\hline 7 & $\begin{array}{l}\text { Hevner, March, } \\
\text { Park, and Ram }\end{array}$ & $\begin{array}{l}\text { Design science in Information } \\
\text { Systems research }\end{array}$ & 2004 & MIS Quarterly & 1528 & 138.9 \\
\hline 8 & $\begin{array}{l}\text { Colquitt, Conlon, } \\
\text { Wesson, Porter, } \\
\text { and } \mathrm{Ng}\end{array}$ & $\begin{array}{l}\text { Justice at the millennium: } \\
\text { A meta-analytic review of } 25 \text { years } \\
\text { of organizational justice research }\end{array}$ & 2001 & $\begin{array}{l}\text { Journal of Applied } \\
\text { Psychology }\end{array}$ & 1352 & 96.6 \\
\hline 9 & Cortina & $\begin{array}{l}\text { What is coefficient alpha - } \\
\text { An examination of theory } \\
\text { and applications }\end{array}$ & 1993 & $\begin{array}{l}\text { Journal of Applied } \\
\text { Psychology }\end{array}$ & 1348 & 61.3 \\
\hline 10 & $\begin{array}{l}\text { Steenkamp and } \\
\text { Baumgartner }\end{array}$ & $\begin{array}{l}\text { Assessing measurement invariance } \\
\text { in cross-national consumer research }\end{array}$ & 1998 & $\begin{array}{l}\text { Journal of Consumer } \\
\text { Research }\end{array}$ & 1304 & 76.7 \\
\hline 11 & Graen and Uhlbien & $\begin{array}{l}\text { Relationship-based approach } \\
\text { to leadership - Development of } \\
\text { leader-member exchange (LMX) } \\
\text { theory of leadership over } 25 \text { years - } \\
\text { Applying a multilevel multidomain } \\
\text { perspective }\end{array}$ & 1995 & Leadership Quarterly & 1265 & 63.3 \\
\hline 12 & Locke and Latham & $\begin{array}{l}\text { Building a practically useful theory } \\
\text { of goal setting and task motivation } \\
\text { - A 35-year odyssey }\end{array}$ & 2002 & $\begin{array}{l}\text { American } \\
\text { Psychologist }\end{array}$ & 1256 & 96.6 \\
\hline 13 & $\begin{array}{l}\text { Schmidt } \\
\text { and Hunter }\end{array}$ & $\begin{array}{l}\text { The validity and utility of selection } \\
\text { methods in personnel psychology: } \\
\text { Practical and theoretical } \\
\text { implications of } 85 \text { years of research } \\
\text { findings }\end{array}$ & 1998 & Psychological Bulletin & 1246 & 73.3 \\
\hline 14 & $\begin{array}{l}\text { Meyer, Allen, } \\
\text { and Smith }\end{array}$ & $\begin{array}{l}\text { Commitment to organizations and } \\
\text { occupations - Extension and test of } \\
\text { a 3-component conceptualization }\end{array}$ & 1993 & $\begin{array}{l}\text { Journal of Applied } \\
\text { Psychology }\end{array}$ & 1176 & 53.5 \\
\hline 15 & $\begin{array}{l}\text { Meyer, Stanley, } \\
\text { Herscovitch, } \\
\text { and Topolnytsky }\end{array}$ & $\begin{array}{l}\text { Affective, continuance, and } \\
\text { normative commitment to the } \\
\text { organization: A meta-analysis } \\
\text { of antecedents, correlates, and } \\
\text { consequences }\end{array}$ & 2002 & $\begin{array}{l}\text { Journal of Vocational } \\
\text { Behavior }\end{array}$ & 1150 & 88.5 \\
\hline 16 & $\begin{array}{l}\text { Hoffman } \\
\text { and Novak }\end{array}$ & $\begin{array}{l}\text { Marketing in hypermedia } \\
\text { computer-mediated environments: } \\
\text { Conceptual foundations }\end{array}$ & 1996 & Journal of Marketing & 1139 & 59.9 \\
\hline
\end{tabular}


Table 6 (Continued)

\begin{tabular}{|c|c|c|c|c|c|c|}
\hline$R$ & Authors & Title & Year & Journal & Cites & $\mathrm{C} / \mathrm{Y}$ \\
\hline 17 & $\begin{array}{l}\text { Williams } \\
\text { and Anderson }\end{array}$ & $\begin{array}{l}\text { Job-satisfaction and organizational } \\
\text { commitment as predictors } \\
\text { of organizational citizenship } \\
\text { and in-role behaviors }\end{array}$ & 1991 & $\begin{array}{l}\text { Journal of } \\
\text { Management }\end{array}$ & 1135 & 47.3 \\
\hline 18 & $\begin{array}{l}\text { Demerouti, } \\
\text { Bakker, } \\
\text { Nachreiner, } \\
\text { and Schaufeli }\end{array}$ & $\begin{array}{l}\text { The job demands-resources model } \\
\text { of burnout }\end{array}$ & 2001 & $\begin{array}{l}\text { Journal of Applied } \\
\text { Psychology }\end{array}$ & 1133 & 80.9 \\
\hline 19 & $\begin{array}{l}\text { Lindell } \\
\text { and Whitney }\end{array}$ & $\begin{array}{l}\text { Accounting for common method } \\
\text { variance in cross-sectional research } \\
\text { designs }\end{array}$ & 2001 & $\begin{array}{l}\text { Journal of Applied } \\
\text { Psychology }\end{array}$ & 1100 & 78.6 \\
\hline 20 & $\begin{array}{l}\text { Podsakoff, } \\
\text { Mackenzie, Paine, } \\
\text { and Bachrach }\end{array}$ & $\begin{array}{l}\text { Organizational citizenship } \\
\text { behaviors: A critical review of the } \\
\text { theoretical and empirical literature } \\
\text { and suggestions for future research }\end{array}$ & 2000 & $\begin{array}{l}\text { Journal of } \\
\text { Management }\end{array}$ & 1060 & 70.7 \\
\hline 21 & $\begin{array}{l}\text { Rhoades and } \\
\text { Eisenberger }\end{array}$ & $\begin{array}{l}\text { Perceived organizational support: } \\
\text { A review of the literature }\end{array}$ & 2002 & $\begin{array}{l}\text { Journal of Applied } \\
\text { Psychology }\end{array}$ & 1050 & 80.8 \\
\hline 22 & Colquitt & $\begin{array}{l}\text { On the dimensionality of } \\
\text { organizational justice: A construct } \\
\text { validation of a measure }\end{array}$ & 2001 & $\begin{array}{l}\text { Journal of Applied } \\
\text { Psychology }\end{array}$ & 1039 & 74.2 \\
\hline 23 & $\begin{array}{l}\text { Wagner, Austin, } \\
\text { Davis, Hindmarsh, } \\
\text { Schaefer, } \\
\text { and Bonomi }\end{array}$ & $\begin{array}{l}\text { Improving chronic illness care: } \\
\text { Translating evidence into action }\end{array}$ & 2001 & Health Affairs & 1030 & 73.6 \\
\hline 24 & $\begin{array}{l}\text { Williams } \\
\text { and O'Reilly }\end{array}$ & $\begin{array}{l}\text { Demography and diversity in } \\
\text { organizations: A review of } 40 \text { years } \\
\text { of research }\end{array}$ & 1998 & $\begin{array}{l}\text { Research in } \\
\text { Organizational } \\
\text { Behavior }\end{array}$ & 1017 & 59.8 \\
\hline 25 & Moorman & $\begin{array}{l}\text { Relationship between } \\
\text { organizational justice and } \\
\text { organizational citizenship behaviors } \\
\text { - Do fairness perceptions influence } \\
\text { employee citizenship }\end{array}$ & 1991 & $\begin{array}{l}\text { Journal of Applied } \\
\text { Psychology }\end{array}$ & 1016 & 42.3 \\
\hline 26 & Bitner & $\begin{array}{l}\text { Servicescapes - The impact of } \\
\text { physical surroundings on customers } \\
\text { and employees }\end{array}$ & 1992 & Journal of Marketing & 999 & 43.4 \\
\hline 27 & $\begin{array}{l}\text { Cronin, Brady, } \\
\text { and Hult }\end{array}$ & $\begin{array}{l}\text { Assessing the effects of quality, } \\
\text { value, and customer satisfaction } \\
\text { on consumer behavioral intentions } \\
\text { in service environments }\end{array}$ & 2000 & Journal of Retailing & 994 & 66.3 \\
\hline 28 & $\begin{array}{l}\text { Schaufeli } \\
\text { and Bakker }\end{array}$ & $\begin{array}{l}\text { Job demands, job resources, and } \\
\text { their relationship with burnout and } \\
\text { engagement: A multi-sample study }\end{array}$ & 2004 & $\begin{array}{l}\text { Journal of } \\
\text { Organizational } \\
\text { Behavior }\end{array}$ & 981 & 89.2 \\
\hline 29 & Grimshaw et al. & $\begin{array}{l}\text { Effectiveness and efficiency of } \\
\text { guideline dissemination and } \\
\text { implementation strategies }\end{array}$ & 2004 & $\begin{array}{l}\text { Health Technology } \\
\text { Assessment }\end{array}$ & 981 & 89.2 \\
\hline 30 & Spector & $\begin{array}{l}\text { Method variance in organizational } \\
\text { research - Truth or urban legend? }\end{array}$ & 2006 & $\begin{array}{l}\text { Organizational } \\
\text { Research Methods }\end{array}$ & 978 & 108.7 \\
\hline 31 & Mael and Ashforth & $\begin{array}{l}\text { Alumni and their alma-mater - } \\
\text { A partial test of the reformulated } \\
\text { model of organizational } \\
\text { identification }\end{array}$ & 1992 & $\begin{array}{l}\text { Journal of } \\
\text { Organizational } \\
\text { Behavior }\end{array}$ & 945 & 41.1 \\
\hline 32 & Kristof & $\begin{array}{l}\text { Person-organization fit: An } \\
\text { integrative review of its } \\
\text { conceptualizations, measurement, } \\
\text { and implications }\end{array}$ & 1996 & Personnel Psychology & 940 & 49.5 \\
\hline
\end{tabular}


Table 6 (Continued)

\begin{tabular}{|c|c|c|c|c|c|c|}
\hline $\mathrm{R}$ & Authors & Title & Year & Journal & Cites & $\mathrm{C} / \mathrm{Y}$ \\
\hline 33 & $\begin{array}{l}\text { Griffeth, Hom, } \\
\text { and Gaertner }\end{array}$ & $\begin{array}{l}\text { A meta-analysis of antecedents and } \\
\text { correlates of employee turnover: } \\
\text { Update, moderator tests, and } \\
\text { research implications for the next } \\
\text { millennium }\end{array}$ & 2000 & $\begin{array}{l}\text { Journal of } \\
\text { Management }\end{array}$ & 937 & 62.5 \\
\hline 34 & Bhattacherjee & $\begin{array}{l}\text { Understanding information systems } \\
\text { continuance: An } \\
\text { expectation-confirmation model }\end{array}$ & 2001 & MIS Quarterly & 916 & 65.4 \\
\hline 35 & Cohen and Bailey & $\begin{array}{l}\text { What makes teams work: Group } \\
\text { effectiveness research from the } \\
\text { shop floor to the executive suite }\end{array}$ & 1997 & $\begin{array}{l}\text { Journal of } \\
\text { Management }\end{array}$ & 899 & 49.9 \\
\hline 36 & $\begin{array}{l}\text { Wanous, Reichers, } \\
\text { and Hudy }\end{array}$ & $\begin{array}{l}\text { Overall job satisfaction: How good } \\
\text { are single-item measures? }\end{array}$ & 1997 & $\begin{array}{l}\text { Journal of Applied } \\
\text { Psychology }\end{array}$ & 898 & 49.9 \\
\hline 37 & Muniz and O'Guinn & Brand community & 2001 & $\begin{array}{l}\text { Journal of Consumer } \\
\text { Research }\end{array}$ & 874 & 62.4 \\
\hline 38 & Chan & $\begin{array}{l}\text { Functional relations among } \\
\text { constructs in the same content } \\
\text { domain at different levels of } \\
\text { analysis: A typology of composition } \\
\text { models }\end{array}$ & 1998 & $\begin{array}{l}\text { Journal of Applied } \\
\text { Psychology }\end{array}$ & 862 & 50.7 \\
\hline 39 & Lee and Ashforth & $\begin{array}{l}\text { A meta-analytic examination of the } \\
\text { correlates of the three dimensions } \\
\text { of job burnout }\end{array}$ & 1996 & $\begin{array}{l}\text { Journal of Applied } \\
\text { Psychology }\end{array}$ & 859 & 45.2 \\
\hline 40 & $\begin{array}{l}\text { Cohen-Charash, } \\
\text { and Spector }\end{array}$ & $\begin{array}{l}\text { The role of justice in organizations: } \\
\text { A meta-analysis }\end{array}$ & 2001 & $\begin{array}{l}\text { Organizational } \\
\text { Behavior and Human } \\
\text { Decision Processes }\end{array}$ & 856 & 61.1 \\
\hline 41 & Hogg and Terry & $\begin{array}{l}\text { Social identity and } \\
\text { self-categorization processes } \\
\text { in organizational contexts }\end{array}$ & 2000 & $\begin{array}{l}\text { Academy of } \\
\text { Management Review }\end{array}$ & 853 & 56.9 \\
\hline 42 & Gist and Mitchell & $\begin{array}{l}\text { Self-efficacy - A theoretical-analysis } \\
\text { of its determinants and malleability }\end{array}$ & 1992 & $\begin{array}{l}\text { Academy of } \\
\text { Management Review }\end{array}$ & 851 & 37.0 \\
\hline 43 & Organ and Ryan & $\begin{array}{l}\text { A meta-analytic review of attitudinal } \\
\text { and dispositional predictors of } \\
\text { organizational citizenship behavior }\end{array}$ & 1995 & Personnel Psychology & 807 & 40.4 \\
\hline 44 & Aaker & Dimensions of brand personality & 1997 & $\begin{array}{l}\text { Journal of Marketing } \\
\text { Research }\end{array}$ & 793 & 44.1 \\
\hline 45 & Conner & $\begin{array}{l}\text { A historical comparison of } \\
\text { resource-based theory and } 5 \text { schools } \\
\text { of thought within } \\
\text { industrial-organization economics - } \\
\text { do we have a new theory of the firm }\end{array}$ & 1991 & $\begin{array}{l}\text { Journal of } \\
\text { Management }\end{array}$ & 791 & 33.0 \\
\hline 46 & Bandura & $\begin{array}{l}\text { Social cognitive theory } \\
\text { of self-regulation }\end{array}$ & 1991 & $\begin{array}{l}\text { Organizational } \\
\text { Behavior and Human } \\
\text { Decision Processes }\end{array}$ & 782 & 32.6 \\
\hline 47 & $\begin{array}{l}\text { Cropanzano } \\
\text { and Mitchell }\end{array}$ & $\begin{array}{l}\text { Social exchange theory: An } \\
\text { interdisciplinary review }\end{array}$ & 2005 & $\begin{array}{l}\text { Journal of } \\
\text { Management }\end{array}$ & 781 & 78.1 \\
\hline 48 & Loewenstein & $\begin{array}{l}\text { Out of control: Visceral influences } \\
\text { on behavior }\end{array}$ & 1996 & $\begin{array}{l}\text { Organizational } \\
\text { Behavior and Human } \\
\text { Decision Processes }\end{array}$ & 780 & 41.1 \\
\hline 49 & $\begin{array}{l}\text { Venkatesh } \\
\text { and Morris }\end{array}$ & $\begin{array}{l}\text { Why don't men ever stop to ask for } \\
\text { directions? Gender, social influence, } \\
\text { and their role in technology } \\
\text { acceptance and usage behavior }\end{array}$ & 2000 & MIS Quarterly & 774 & 51.6 \\
\hline 50 & $\begin{array}{l}\text { Weiss and } \\
\text { Cropanzano }\end{array}$ & $\begin{array}{l}\text { Affective events theory: A } \\
\text { theoretical discussion of the } \\
\text { structure, causes and consequences } \\
\text { of affective experiences at work }\end{array}$ & 1996 & $\begin{array}{l}\text { Research in } \\
\text { Organizational } \\
\text { Behavior }\end{array}$ & 761 & 40.1 \\
\hline
\end{tabular}




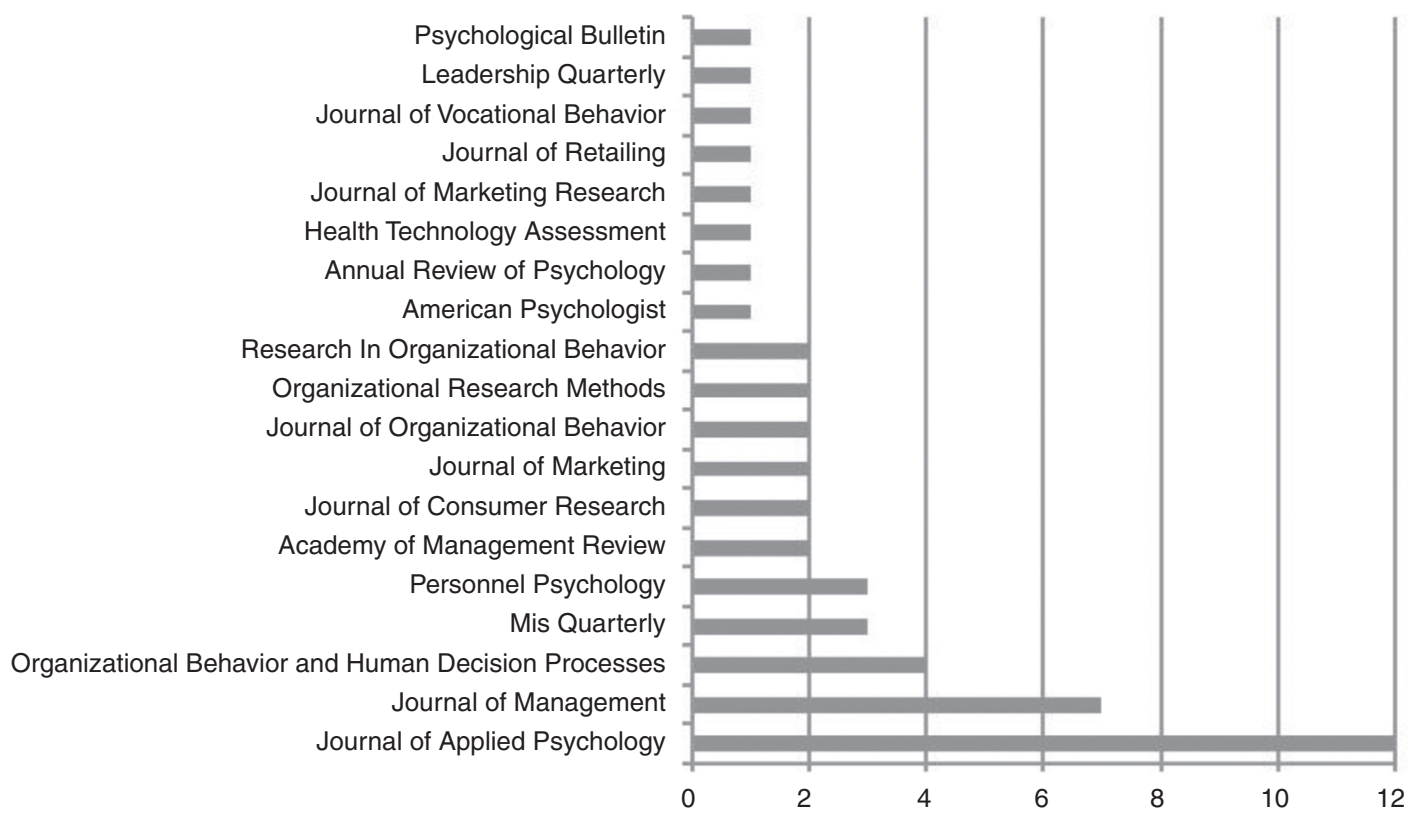

Figure 3 Top-50 papers by journal.

with Philip M. Podsakoff as a co-author in both), John P. Meyer (JAP, 1993 and the Journal Vocational Behavior, 2002), Philip M. Podsakoff (JOM, 2000 and JAP, 2003, with Scott B. MacKenzie as a co-author in both), and Paul E. Spector (OBHDP, 2001 and Organizational Research Methods, 2006).

\section{Conclusion}

The main objective of our research was to analyze the scientific productivity in one of the specific areas of psychology, the WOP, in the last 25 years (1991-2015). To do so, our bibliometric study focuses on the most influential journals and articles, generally and for 5-year periods, as well as structures of co-citation among the highest quality journals based on their $h$-index on the Thompson Reuters Journal Citation Reports (JCR).

Similarly to the results of other authors focusing on other disciplines, we found that a high percentage of papers published each year receive between 5 and 10 cites. On the other hand, the number of papers that receive 100 or more citations is above the usual number of citations in other areas (Merigó, Mas-Tur, et al., 2015).

Secondly, we observe an exponential increase in the number of papers published, citations, and $h$-index. Several authors have noted this increasing in various fields of knowledge (e.g., Bonilla et al., 2015; Goldberg et al., 2015; Simsek et al., 2013), pointing out it may be causing bias on indexes commonly used to determine the impact of a journal (Goldberg et al., 2015).

Additionally, the number of self-citations significantly increases in the last 5 years. It is likely that the observed trends will be corrected in the future, due to the consolidation process of the papers. In this sense, we consider that the most recent papers need more time to increase their level of citation and, subsequently, to correct the bias on self-citation. Other studies pointed out that the percentage of self-citation is usually around $10 \%$ (Krampen, 2010; Krampen, Becker, Wahner, \& Montada, 2007) and consider that "self-references should not only be viewed as self-marketing strategies of scientists, but as indicators of the continuity of the research they have undertaken (representing central themes of their work) as well", (Krampen, 2010, p. 513). Additionally, social science papers need more than 5 years to increase their number of cites, while this time is around three years for natural sciences papers (Salgado \& Páez, 2007).

Related to the journals, the Journal of Applied Psychology (JAP) is the most influential journal in WOP field, based on its $h$-index. It is on the second position (of 76) in the WoS "Psychology - Applied" category and on the sixth position (of 185) in "Management"'. When we analyze citations per paper $(\mathrm{C} / \mathrm{P})$, the Journal of Consumer Behaviour (JCB) is the first one. If we compare the JAP with the JCB we can see that, although both journals have the same number of annual volumes in recent years, the number of papers they include is substantially different (around 20 in JAP and less than 10 in JCB).

The JAP is also in second position on impact factor (IF2014) and on 5-year impact factor, being surpassed by the Journal of Management (JOM). In this sense, the JOM can also be considered as one of the most influential journal in the field of WOP.

If we only consider the number of papers published, the result is affected by the number of volumes and papers published in them (around 20 papers in each of the six annual volumes in the JAP compared to 11 papers in the 7 annual volumes in the JOM). Finally, another indicator of the relevance of the JAP and the JOM in the area under study is that 12 and 7 of the 50 most cited articles of the last 25 years have been published in JAP and JOM respectively (a total of $38 \%$ of the top-50 most influential papers). The knowledge flow shows that, being the JAP the most cited 
journal, only $4.27 \%$ of its citations comes from the other top- 5 journals. Related to co-citation, the Journal of Applied Psychology is again the leading journal, although some other psychology and management journals also have a significant position, as the Journal of Personality and Social Psychology, the Academy of Management Journal, or the Academy of Management Review.

The most influential papers of the top-50 list is "The theory of planned behavior" (Ajzen, 1991). This is the most cited in absolute terms, but "Common method biases in behavioral research. A critical review of the literature and recommended remedies"' (Podsakoff, MacKenzie, Lee, \& Podsakoff, 2003) receives more citations on average (citations/year). The first paper has an epistemological sense, developing one of the most important conceptual frameworks to explain individuals thinking and behaviors. On the other hand, Podsakoff's paper analyzes critically one of the most common methodological problems, the common method variance. In this sense, his analysis is entirely relevant to researchers when designing their own research, as it provides recommendations for controlling method biases in research settings.

Schaufeli is the author with more papers in the top-50 (Demerouti, Bakker, Nachreiner, \& Schaufeli, 2001; Maslach, Schaufeli, \& Leiter, 2001; Schaufeli \& Bakker, 2004). His papers analyze the causes and consequences of one of the most important and controversial syndrom for researchers and practitioners, the burnout (Maslach, 1978).

Due to the interdisciplinary nature of work and organizational psychology, researchers publish their results in diverse scientific journals of different knowledge areas, mainly psychology and management (König et al., 2015). This is a great strength, as it contributes sharing knowledge in various fields, but also implies a difficulty because researchers have to open the focus of analysis in conceptually and methodologically terms. An important object of interest for research is the analysis of the scientific journals and articles included on the Web of Science (Viseu et al., 2015). In this, the present study contributes to analyze a specific area of Psychology that has been scarcely studied.

\section{Acknowledgement}

In Memoriam Dr. Robert R. Roe, Founding-President of the European Association of Work and Organizational Psychology (EAWOP) and President of the Advisory Board, Master Erasmus Mundus on Work, Organizational and Personnel Psychology (WOP-P).

\section{References}

Aguinis, H., Bradley, K. J., \& Brodersen, A. (2014). Industrial-organizational psychologists in business schools: Brain drain or eye opener? Industrial and Organizational Psychology, 7, 284-303.

Ajzen, I. (1991). The theory of planned behavior. Organizational Behavior and Human Decision Processes, 50, 179-211.

Albayrak, Ö., Föcker, M., Wibker, K., \& Hebebrand, J. (2012). Bibliometric assessment of publication output of child and adolescent psychiatric/psychological affiliations between 2005 and 2010 based on the databases PubMed and Scopus. European Child \& Adolescent Psychiatry, 21, 327-337.
Allik, J. (2013a). Personality psychology in the first decade of the new millennium: A bibliometric portrait. European Journal of Personality, 27, 5-14.

Allik, J. (2013b). Bibliometric analysis of the journal of cross-cultural psychology during the first ten years of the new millennium. Journal of Cross-Cultural Psychology, 44, 657-667.

Aluja, A., Becoña, E., Botella, C., Colom, R., Echeburúa, E., Forns, M., ..., \& Vila, J. (2011). Indicadores de calidad de la producción en la Web of Science de diez profesores del Área de Personalidad, Evaluación y Tratamiento Psicológico: aportaciones adicionales al estudio de Olivas-Ávila y Musi-Lechuga. Psicothema, 23, 267-273.

Amin, R., \& Mabe, M. (2003). Impact factor: Use and abuse. Medicina, 63, 347-354.

Ariza, T., \& Reina Granados, M. (2012). Bibliometric analysis of the most relevant Iberoamerican journals related to Clinical and Health Psychology of the journal citation reports. Terapia Psicológica, 30, 89-102.

Bonilla, C. A., Merigó, J. M., \& Torres-Abad, C. (2015). Economics in Latin America: A bibliometric analysis. Scientometrics, 105, 1239-1252.

Campanario, J. M. (2011). Empirical study of journal impact factors obtained using the classical two-year citation window versus a five-year citation window. Scientometrics, 87, 189-204.

Campanario, J. M., González, L., \& Rodríguez, C. (2006). Structure of the impact factor of academic journals in the field of Education and Educational Psychology: Citations from editorial board members. Scientometrics, 69, 37-56.

Cikara, M., Rudman, L., \& Fiske, S. (2012). Dearth by a thousand cuts? Accounting for gender differences in top-ranked publication rates in social psychology. Journal of Social Issues, 68, 263-285.

Demerouti, E., Bakker, A. B., Nachreiner, F., \& Schaufeli, W. B. (2001). The job demands-resources model of burnout. Journal of Applied Psychology, 86, 499-512.

Garfield, E. (1972). Citation analysis as a tool in journal evaluation. Science, 178, 471-479.

Glanzel, W., \& Moed, H. F. (2002). Journal impact measures: Their role in research policy and scientific information management. Scientometrics, 53, 169-170.

Goldberg, S. R., Anthony, H., \& Evans, T. S. (2015). Modelling citation networks. Scientometrics, 105, 1577-1604.

Haslam, N., Ban, L., Kaufmann, L., Loughnan, S., Peters, K., Whelan, J., \& Wilson, S. (2008). What makes an article influential? Predicting impact in social and personality psychology. Scientometrics, 76, 169-185.

Haslam, N., \& Kashima, Y. (2010). The rise and rise of social psychology in Asia: A bibliometric analysis. Asian Journal of Social Psychology, 13, 202-207.

Haslam, N., \& Lusher, D. (2011). The structure of mental health research: Networks of influence among psychiatry and clinical psychology journals. Psychological Medicine, 41, 2661-2668.

Hirsch, J. E. (2005). An index to quantify an individual's scientific research output. Proceedings of the National Academy of Sciences of the United States of America, 102, 16569-16572.

Hirsch, J. E., \& Buela-Casal, G. (2014). The meaning of the hindex. International Journal of Clinical and Health Psychology, 14, 161-164.

König, C. J., Fell, C. B., Kellnhofer, L., \& Schui, G. (2015). Are there gender differences among researchers from industrial/organizational psychology? Scientometrics, 105, 1931-1952.

Krampen, G. (2010). Acceleration of citing behavior after the millennium? Exemplary bibliometric reference analyses for psychology journals. Scientometrics, 83, 507-513. 
Krampen, G., Becker, R., Wahner, U., \& Montada, L. (2007). On the validity of citation counting in science evaluation: Content analyses of references and citations in psychological publications. Scientometrics, 71, 191-202.

Lepach, A. C., Lehmkuhl, G., \& Petermann, F. (2010). Neuropsychologische Themen in der Kinderpsychologie und Kinderpsychiatrie. Praxis der Kinderpsychologie und Kinderpsychiatrie, 59, 576-587.

Lillo, S., \& Martini, N. (2013). Principales Tendencias Iberoamericanas en Psicología Clínica. Un Estudio Basado en la Evidencia Científica. Terapia Psicológica, 31, 363-371.

Maslach, C. (1978). The client role in staff burn-out. Journal of Social Issues, 34, 111-124.

Maslach, C., Schaufeli, W. B., \& Leiter, M. P. (2001). Job burnout. Annual Review of Psychology, 52, 397-422.

Merigó, J. M., Gil-Lafuente, A. M., \& Yager, R. R. (2015). An overview of fuzzy research with bibliometric indicators. Applied Soft Computing, 27, 420-433.

Merigó, J. M., Mas-Tur, A., Roig-Tierno, N., \& Ribeiro-Soriano, D. (2015). A bibliometric overview of the Journal of Business Research between 1973 and 2014. Journal of Business Research, 68, 2645-2653.

Podsakoff, P. M., Mackenzie, S. B., Lee, J. Y., \& Podsakoff, N. P. (2003). Common method biases in behavioral research: A critical review of the literature and recommended remedies. Journal of Applied Psychology, 88, 879-903.

Podsakoff, P. M., MacKenzie, S. B., Podsakoff, N. P., \& Bachrach, D. G. (2008). Scholarly influence in the field of management: A bibliometric analysis of the determinants of university and author impact in the management literature in the past quarter century. Journal of Management, 34, 641-720.
Quevedo-Blasco, R., Zych, I., \& Buela-Casal, G. (2014). Sleep apnea through journal articles included in the Web of Science in the first decade of the 21st century. Revista Iberoamericana de Psicología y Salud, 5, 39-53.

Salgado, J. F., \& Páez, D. (2007). La productividad científica y el índice h de Hirchs de la psicología social española: convergencia entre indicadores de productividad y comparación con otras áreas. Psicothema, 19, 179-189.

Schaufeli, W. B., \& Bakker, A. B. (2004). Job demands, job resources, and their relationship with burnout and engagement: A multi-sample study. Journal of Organizational Behavior, 25, 293-315.

Simsek, Z., Heavey, C., \& Jansen, J. J. (2013). Journal impact as a diffusion process: A conceptualization and the case of the Journal of Management Studies. Journal of Management Studies, 50, 1374-1407.

Small, H. (1973). Co-citation in the scientific literature: A new measure of the relationship between two documents. Journal of the American Society for Information Science, 24, 265-269.

Van Eck, N. J., \& Waltman, L. (2010). Software survey: VOS viewer, a computer program for bibliometric mapping. Scientometrics, 84, 523-538.

Vinluan, L. R. (2012). Research productivity in education and psychology in the Philippines and comparison with ASEAN countries. Scientometrics, 91, 277-294.

Viseu, J. N., de Jesus, S. N., Quevedo-Blasco, R., Rus, C. L., \& Canavarro, J. M. (2015). Motivação docente: estudo bibliométrico da relação com variáveis individuais, organizacionais e atitudes laborais. Revista Latinoamericana de Psicología, 47, 58-65. 